\title{
Tilting toward secrecy
}

\author{
A European high court ruling on the patentability of inventions related to human embryonic stem cells could promote \\ secrecy and reduce access to data and cell lines.
}

The he decision by the Court of Justice of the European Union (CJEU) to restrict patents on human embryonic stem cells (hESCs) has sent shock waves through the research community in recent weeks. On the one hand, some say the ruling could unshackle hESC science from the constraints of intellectual property (IP) thickets and licensing red tape. On the other, funding for translational research in European startups and companies may also suffer. Whatever the case, the judgment seems likely to increase industry's reliance on secrecy and inhibit the open sharing of research results.

The legal framework governing the patentability of inventions related to hESCs was established in the 1998 European Union directive "on the legal protection of biotechnological inventions." European legislators left ample room for patents on biological material by applying the same criteria used in other areas of technology: "novelty, inventive step and industrial application." But they also reaffirmed earlier European laws that prohibited patenting of inventions contrary to "ordre public or morality," described as inventions whose commercial exploitation should be prevented to "protect human, animal or plant life or health or to avoid serious prejudice to the environment." The directive provided a few examples of such unpatentable biotech inventions, including human reproductive cloning, human germline genetic modification and, in Article 6(2)(c), "uses of human embryos for industrial or commercial purposes." HESCs are not mentioned anywhere in the document; indeed, these cells were not reported in the literature until several months after it had been voted into law.

Once a European Union directive is adopted, it is up to the member states to implement it by passing appropriate legislation. At least some of the member states concluded that hESC patents were still acceptable. In the United Kingdom, for example, the Intellectual Property Office decided in 2003 that patents could be granted on pluripotent or multipotent stem cells but not on totipotent stem cells. At the European Patent Office, a 2008 decision by the Enlarged Board of Appeal on an application from the Wisconsin Alumni Research Foundation (WARF) forbid patents on products that "at the filing date could be prepared exclusively by a method which necessarily involved the destruction of the human embryos from which the said products are derived, even if the said method is not part of the claims." Although the WARF application was denied, the decision in fact gave considerable latitude to hESC patents. Claims that could have been put into practice without destroying embryos were subsequently held permissible if they had been filed after hESC lines became available.

This status quo must now be reevaluated in light of the October 18 judgment of the CJEU in the case of Brüstle v Greenpeace (see p. 1057). The ruling - a binding interpretation of the biotech directive's Article $6(2)(c)$ - states that an invention is unpatentable "where the implementation of the invention requires the destruction of human embryos" even if there is no mention of embryos in the claims and the embryo destruction occurred "at a stage long before the implementation of the invention, as in the case of the production of embryonic stem cells."

The implications of the CJEU's decision for stem cell research and commercialization in Europe have been widely discussed. One point of view is that progress in the stem-cell field is being hampered by an overabundance of patents and the absence of a complete, searchable database on these patents. But many observers have noted that a lack of patent protection will further dissuade investors from supporting risky hESC product development. And scientists and others have rightly denounced the CJEU's equation of hESC research and patents with désordre public or immorality, which stigmatizes the entire field. Undoubtedly, the decision will abolish some amount of existing IP as certain patents become unenforceable. The effects are likely to weigh more heavily on small startups and university spin-offs, whose value is closely tied to their patent portfolios, than on larger, more established companies.

The long-term impact of the CJEU's ruling is uncertain, but the European patent attorneys who spoke with Nature Biotechnology are generally optimistic that hESC science and clinical translation in Europe are not in danger. To begin with, methods that do not destroy embryos and do not use embryos as base material, such as methods involving induced pluripotent stem cells (iPSCs), will still be patentable. HESC research will still be patentable in jurisdictions outside Europe, including the large US and Asian markets. Moreover, companies can protect their IP using other strategies, such as trade secrets and regulatory data exclusivity.

Huw Hallybone, of London's Carpmaels \& Ransford, believes that any patent claims related to hESCs generated through the destruction of embryos-for example, claims on methods to expand or differentiate the cells or to deliver hESC derivatives to patients-will likely be excluded under the new ruling. But he also says that "the decision could make Europe a haven for companies using hESCs because there is no risk that they would infringe on others' patents." George Schlich, of Littlehampton, UK-based Schlich \& Co., argues that any hESC patent filed after alternative, nonembryo-destroying cells became availablesuch as human iPSCs (first published on November 20,2007) or possibly cells derived through preimplantation genetic diagnosis-will remain valid because it is plausible that a skilled person could have used these alternative cells instead of hESCs. Schlich says this means that older filings are in trouble, but "the future for patenting stem cell inventions in Europe could not be better."

If options to patent remain open, as he says, then all may be well. But if Europe turns into an hESC patent-free zone, expect translational research to retreat behind closed doors, trade secrets to dominate and open publication of industry data to move from rare to extinct. 